\title{
Validity test of anti-c1q serum as diagnostic marker for lupus nephritis
}

\author{
M Enrica' , A Tjandrawati' , S Rachmayati' ${ }^{1}$ L Hamijoyo²
}

1 Department of Clinical Pathology, Padjadjaran University School of Medicine/Hasan Sadikin General Hospital ${ }^{2}$ Division of Rheumatology, Department of Internal Medicine, Padjadjaran University School of Medicine/ Hasan Sadikin General Hospital

\begin{abstract}
Background: Lupus nephritis is defined as renal involvement in systemic lupus erythematosus (SLE) patients and the most important cause of morbidity and mortality. The diagnostic criteria that used to diagnose lupus nephritis are 1997 American College of Rheumatology is 24 hours urine protein $\geq 500 \mathrm{mg}$ and/or cellular cast, but significant renal damage can occur without proteinuria or cellular cast. Anti-C1q is an autoantibody that is produced by a chronic alteration of $\mathrm{C} 1 \mathrm{q}$ collagen domain. Anti-C1q is a new specific marker for renal marker.
\end{abstract}

Objective: To determine the validity of anti-C1q serum by using 1997 American College of Rheumatology criteria as a gold standard.

Methods: This is a cross sectional study, conducted in October to December 2014 at Hasan Sadikin Hospital Bandung. The subjects had systemic lupus erythematosus with and without renal involvement, based on 1997 American College of Rheumatology criteria for SLE.

Results: There were 65 subjects included in this study, 64 subjects were female and 1 subject was male. The age average was 32 (SD 11.7) years old. As many as $66.2 \%$ subjects had been diagnosed with lupus erythematosus systemic at least 3 years. Twenty four hours urine protein was measured using spectrophotometry, urine sediment was examined for cellular cast, and anti-C1q serum was measured using micro enzyme linked immunosorbent assay. Based on American College of Rheumatology criteria, 34 subjects were classified as lupus nephritis group while 31 subjects were classified as non-lupus nephritis group. The area under the curve of anti-C1q was 0.610. The cut-off value used in this study was $10.43 \mathrm{U} / \mathrm{ml}$. The sensitivity, specificity, positive predictive value, negative predictive value and accuracy of anti-C1q assay were $41.18 \%, 77.42 \%, 66.67 \%, 54.55 \%$ and $58.46 \%$ respectively.

Conclusion: Anti-C1q assay, based on this study, has a low sensitivity and medium specificity to detect lupus nephritis.

Kidney is the most common organ involvement on systemic lupus erythematosus (SLE). ${ }^{1}$ Approximately $55 \%$ of SLE patients developing nephritis during the first 10 years of disease and approximately more than $25 \%$ of these patients will suffer end-stage renal disease within the first 10 years. ${ }^{2,3}$ The presence of lupus nephritis significantly reduces survival to approximately $88 \%$ at 10 years. ${ }^{2}$ Until now, lupus nephritis is still make a significant mortality and morbidity of SLE patients. Therefore, there is an urgent need for a lupus nephritis diagnostic marker.

Renal biopsy is the gold standard for lupus nephritis, however biopsy relatively expensive and need special equipment. Therefore, renal biopsy is not practical enough as a routine examination. The diagnostic criteria for lupus nephritis based on 1997 American College of Rheumatology (ACR) are 24 hours urine protein $\geq 500 \mathrm{mg}$ and or cellular/granular cast. However the criteria has limitations, that significant renal damage can occur without proteinuria or cast in the urine. ${ }^{4}$ Anti-C1q is an autoantibody that is produced by a chronic change of $\mathrm{Clq}$ collagen domain. Anti-C1q only produced when $\mathrm{Clq}$ is in its bound form, therefore the pathological role of anti-C1q is local, and specific for lupus nephritis. ${ }^{5,6}$ Several studies had been conducted to investigate anti-C1q, however the studies are controversial. Moura et al. ${ }^{7}$ in 2011 found that anti-C1q serum has $86.66 \%$ sensitivity, $74.4 \%$ specificity, $52 \%$ positive predictive value, $94.59 \%$ negative predictive value for the diagnosis of lupus nephritis. Moura concluded that anti-C1q can be used as a lupus nephritis diagnostic marker therefore reduced renal biopsy. Meyer et al. ${ }^{8}$ in 2009 found anti-C1q serum has 100\% sensitivity, $95.7 \%$ specificity, $100 \%$ positive predictive value, $50 \%$ negative predictive value. In contrary, Katsumata et al. ${ }^{9}$ found that anti-C1q serum level was correlated with lupus global activity and not correlated with lupus nephritis. Heindenreich et al. ${ }^{10}$ also found anti-C1q validity was lower than anti-dsDNA in diagnosing lupus nephritis. This study aimed to determine the validity of anti-C1q serum using 1997 American College of Rheumatology criteria for SLE as a gold standard.

\section{METHODS}

\section{Study design}

This is an analytical-observational study with cross-sectional design. The study was performed at Rheumatology Clinics/Division of Rheumatology of the Department of Internal Medicine and Clinical Pathologic Department at Hasan Sadikin General 
Hospital, Bandung from October 2014 until December 2014. This study has passed the ethical clearance set by the ethical committee.

\section{Subjects}

The subjects of this study were patients that have been diagnosed as SLE with and without renal involvement based on ACR criteria and have been receiving immunosuppressant therapy, in Rheumatology Clinics at Hasan Sadikin General Hospital. The sample size was calculated using formula for diagnostic test. The minimal sample for this study was 65 samples. All participants have given consent to be enrolled in this study.

The inclusion criteria were SLE patients with and without renal involvement. The exclusion criteria were patients in their menstrual cycle; urinary tract infection; other glomerulopathies; inadequate 24-hours urine collection, serum with hemolysis, icteric or lipemia; icteric 24-hours urine. History taking was done in all patients to collect demographic characteristics and laboratory test according to the needs for data collection.

Blood, spot urine and 24-hours urine collection were performed to acquire necessary data. Serum was obtained from phlebotomy to measure anti-C1q. Serum was collected in the $-20^{\circ} \mathrm{C}$ until the minimal sample acquired. Anti-C1q was assayed using indirect micro enzyme linked immunosorbent assay (Orgentec, Germany). The measurement scale is numeric.

Spot urine was collected from the midstream urine. Routine urinalysis and sediment analysis was performed for all subjects. Total urine creatinine was done before protein urine examination to determine 24-hours urine adequacy. Inadequate 24-hours urine was determined as ratio (predicted creatinine- total urine creatinine)/ predicted creatinine $>0.2$. The inadequate 24-hours urine was excluded if the second 24-hours urine recollection was inadequate. Twenty-four hours urine protein determined by spectrophotometry.

The collection of the specimens was done at outpatient's laboratory, Clinical Pathologist Department, Hasan Sadikin Hospital. Routine urine examination and total urine protein was examined at Chemical Division, Clinical Pathologist Department, Hasan Sadikin Hospital. Anti-C1q serum was examined at Immunoserology Division, Clinical Pathology Department, Hasan Sadikin Hospital.

The data collected were processed using Statistical Package for the Social Sciences (SPSS) program. KolmogorovSmirnov test was used to describe the data distribution. Receiver operating characteristics was used to determined cut-off value and validity testing was used to determined sensitivity, specificity, positive predictive value, negative predictive value and accuracy.

\section{RESULTS}

During the study timeline, informed consent was done to 85 subjects. Fourteen subjects were excluded because of urinary tract infection and 4 subjects because of menstrual period. Inadequate 24-hours urine collection was found in 5 subjects, therefore the collection was repeated. Three subjects eventually met the criteria, while 2 other subjects were not met the criteria. Sixty five subjects were classified into 2 groups, which were 34 subjects with lupus nephritis and 31 subjects without lupus nephritis. The age mean in lupus nephritis group was 31.23 years old, while in non-lupus nephritis group was 34.43 years old. Characteristics of subjects are presented in Table 1.

Table 1 Characteristics of subjects

\begin{tabular}{|c|c|c|c|}
\hline Variable & $\begin{array}{c}24 \text {-hours urine } \\
\text { protein } \geq \\
500 \text { mg and or } \\
\text { cellular cast } \\
(n=34)\end{array}$ & $\begin{array}{c}24-h o u r s \text { urine } \\
\text { protein }<500 \\
\text { mg without } \\
\text { cellular cast } \\
(n=31)\end{array}$ & $\mathbf{p}$ \\
\hline Age (years old) & & & $\left.0.274^{*}\right)$ \\
\hline Mean (SD) & $31.23(11.17)$ & $34.43(12.25)$ & \\
\hline \multicolumn{4}{|l|}{$\begin{array}{l}\text { Age at SLE } \\
\text { diagnosed (years } \\
\text { old) }\end{array}$} \\
\hline Mean & 27.31 & 28.73 & $\left.0.582^{*}\right)$ \\
\hline SD & 10.01 & 10.75 & \\
\hline \multicolumn{4}{|l|}{ Gender } \\
\hline Male & $1(1.5 \%)$ & $0(0 \%)$ & $\left.0.538^{* *}\right)$ \\
\hline Female & $33(50.8 \%)$ & $31(47.7 \%)$ & \\
\hline \multicolumn{4}{|l|}{ Duration of illness } \\
\hline$<3$ years & $14(21.5 \%)$ & $8(12.3 \%)$ & $\left.0.385^{* *}\right)$ \\
\hline$\geq 3$ years & $20(30.8 \%)$ & $23(35.4 \%)$ & \\
\hline \multicolumn{4}{|l|}{ Chief complaints } \\
\hline Photosensitivity & \multicolumn{2}{|c|}{$2(3 \%)$} & \\
\hline Malar rash & \multicolumn{2}{|c|}{$7(11 \%)$} & \\
\hline Lupus hair & \multicolumn{2}{|c|}{$11(17 \%)$} & \\
\hline Arthralaia & \multirow{2}{*}{\multicolumn{2}{|c|}{$5(8 \%)$}} & \\
\hline Arthralgia & & & \\
\hline Fatigue & \multicolumn{2}{|c|}{$\begin{array}{l}5(8 \%) \\
1(1 \%)\end{array}$} & \\
\hline Ankle edema & \multirow{2}{*}{\multicolumn{2}{|c|}{$34(52 \%)$}} & \\
\hline Without complaint & & & \\
\hline
\end{tabular}

${ }^{*}$ Independent t-test ${ }^{* *}$ chi square test

$\mathrm{n}=$ total subject, $\mathrm{SD}=$ standard deviation, $\mathrm{p}=$ probability

Sensitivity and specificity value for various anti-Clq cut off value are presented in Table 2. Cut off value used in this study is $10.43 \mathrm{U} / \mathrm{ml}$ with $40 \%$ sensitivity and $76.6 \%$ specificity.

Table 2 Sensitivity and specificity value for various anti-C1q cut off value

\begin{tabular}{ccc}
\hline $\begin{array}{c}\text { Anti-C1q cut-off } \\
\text { value (U/m) }\end{array}$ & Sensitivity (\%) & Specificity (\%) \\
\hline$\geq 1.10$ & 94.3 & 23 \\
$\geq 2.15$ & 94.3 & 30 \\
$\geq 2.35$ & 88.6 & 30 \\
$\geq 2.55$ & 85.7 & 30 \\
$\geq 3.05$ & 74.3 & 30 \\
$\geq 4.05$ & 62.9 & 46.7 \\
$\geq 5.76$ & 51.4 & 66.7 \\
$\geq 6.91$ & 45.7 & 70 \\
$\geq 8.00$ & 45.7 & 73.3 \\
$\geq 10.43$ & 40 & 76.7 \\
$\geq 12.22$ & 37 & 76.7 \\
\hline
\end{tabular}

Receiver operating characteristics curve for anti-Clq is presented in Figure 1. Area under the curve for anti-C1q was 
0.610 . Validity testing results for anti-C1q with cut off value $10.43 \mathrm{U} / \mathrm{ml}$ were $41.18 \%$ sensitivity, $77.42 \%$ specificity, $66.67 \%$ positive predictive value, $54.55 \%$ negative predictive value and $58.46 \%$ accuracy, is presented in Table 3 .

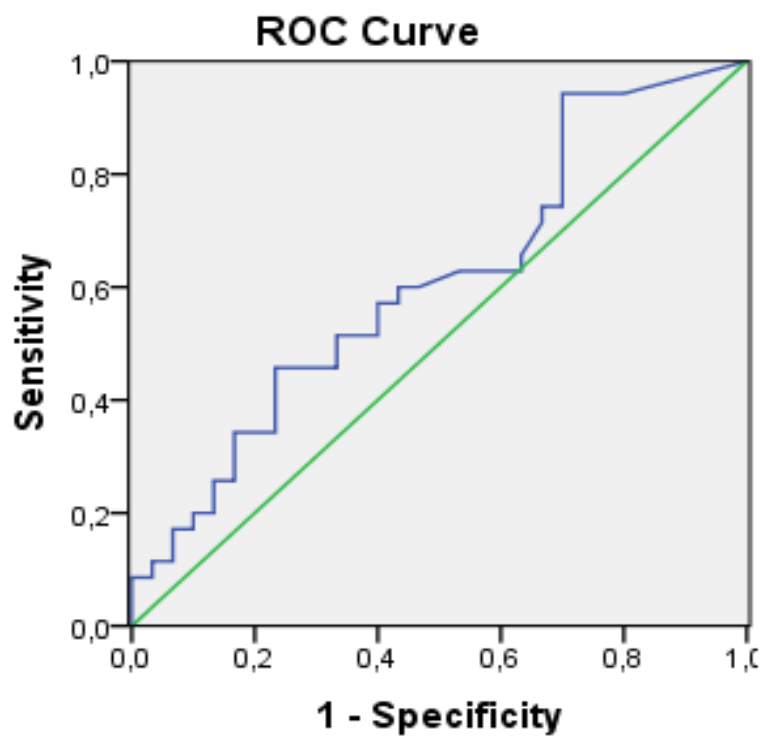

Diagonal segments are produced by ties.

Figure 1 Receiver operating characteristics curve for anti-C1q

Table 3 Validity testing Anti-C1q in Lupus Nephritis

\begin{tabular}{lccc}
\hline \multirow{2}{*}{ Variable } & \multicolumn{2}{c}{ Lupus Nephritis } & \\
\cline { 2 - 3 } & $\begin{array}{c}\text { 24-hours urine } \\
\text { protein } \mathbf{2} \\
\mathbf{5 0 0} \mathbf{~ m g} \text { and or } \\
\text { cellular cast } \\
\text { ( } \mathbf{n = 3 4 )}\end{array}$ & $\begin{array}{c}\text { 24-hours urine } \\
\text { protein }<\mathbf{5 0 0} \\
\text { mg without } \\
\text { cellular cast } \\
\text { ( } \mathbf{n = 3 1 )}\end{array}$ & \\
\hline Anti-C1q & & & \\
Positive $\geq 10.43 \mathrm{U} / \mathrm{ml}$ & 14 & 7 & 21 \\
Negative $<10.43 \mathrm{U} / \mathrm{ml}$ & 20 & 24 & 44 \\
\hline Total & 34 & 31 & 65 \\
\hline
\end{tabular}

\section{DISCUSSION}

It is already known that lupus nephritis has higher incidence and prevalence among Asian patients, with lower survival rate. Renal biopsy is a gold standard for diagnosing lupus nephritis but biopsy is relatively more expensive than conventional parameters (urine protein and cellular/granular cast). However, significant renal damage can take place without proteinuria or cast. Therefore this study was aimed to determine the validity of anti-C1q as the new marker for lupus nephritis.

The age average of the subjects was 32.71 years old with 27.99 years old as the age average at the time of SLE diagnosed. This age average does not differs from other studies, which stated that SLE can occur at any age, but the most common age is 10-50 years old. Approximately $85 \%$ SLE happens before 50 and $20 \%$ happens in less than 16 years old. Younger SLE patients was correlated with worse prognosis and manifestation, especially renal manifestation. ${ }^{11}$

The female gender was more common gender in this study. Systemic lupus erythematosus was more common in female (83-97\%) with 9:1 ratio. This ratio increased to 11:1 in reproductive age of the female. Although the exact etiology of SLE was not been determined, these fact causing a theory that hormonal factor acts as a risk factor for SLE. ${ }^{4}$

Majority of the subjects (66.2\%) have been diagnosed SLE for $\geq 3$ years. Duration of illness was measured since lupus nephritis can develop in early and late onset of SLE. Lupus nephritis that occur during the early onset of SLE is one of the factor that determine worse prognosis of SLE. ${ }^{12}$

Photosensitivity, malar rash, lupus hair, is mucocutaneous manifestation of SLE, while arthralgia is musculoskeletal manifestation. ${ }^{13,14}$ Fatigue can happen in 50-90\% SLE patients and can be related to depression or pain. ${ }^{15}$ Edema is one of renal manifestation, found in one subject which has proteinuria $>3500 \mathrm{mg} / 24$ hours. $^{12}$

\section{Validity of anti-C1q Serum}

Cut off used in this study is $10.43 \mathrm{U} / \mathrm{ml}$ since this value produced highest specificity, in line with the aim of this study. Cut-off $2.15 \mathrm{U} / \mathrm{ml}$ produced highest sensitivity but it cannot be used as cut off value since this value can be found in normal population (range $0.9-4.2 \mathrm{U} / \mathrm{ml}){ }^{16}$

The result of this study is different from Moura or Meyer study that showed a good sensitivity and specificity of antiC1q serum. This study only showed moderate specificity $(77.42 \%)$ and poor sensitivity (41.18\%). Several factors may contribute to this discrepancy.

Twenty out of 34 subjects produced false negative value. False negative value will affect sensitivity value. False negative value can be explained by several factors, such as immunosuppressant and/or chemotherapy that have been given to the subjects. Immunosuppressant therapy is drugs that suppress immune response so it can alter anti-C1q serum level. Chemotherapy is an alkylating agent that induced cell death includes B cell. B cell reduction will also reduce antiC1q serum level.

In some subjects, lupus nephritis was determined only by granular cast. Some subjects have urine protein range from $510.4-690 \mathrm{mg} / \mathrm{dl}$. Urine protein level and urinary cast are used to determine the severity of lupus nephritis. Cai et al. ${ }^{17}$ stated that anti-C1q serum level positively correlated with renal damage level and there were significant difference between classes II, III and IV lupus nephritis. These subjects can be classified as class I or class II, with minimal renal damage, so that anti-C1q level possibly still low.

Other factor that may contribute to false negative results is anti-C1q binding as immune complexes in glomerulus. Mannik et al. ${ }^{18}$ found that anti-C $1 \mathrm{q} / \mathrm{IgG}$ ratio in glomerulus was 50 times higher than anti-Clq/IgG ratio in serum, therefore causing a lower level of anti-C1q in serum.

Proteinuria was used as gold standard in this study, however proteinuria has several limitations. Persistent proteinuria not always correlated with renal inflammation but can occur in urinary tract infection or other glomerulopathy. This condition had been excluded in this study.

Seven out of 31 subjects produced false positive results. False positive value will affect specificity value. These can 
be explained by several factors. Proteinuria and/or cast were used as the gold standard in this study. Stine and Arenas stated a condition called silent lupus nephritis, condition, which significant renal damage occurs without proteinuria and or urinary cast. ${ }^{19,20}$ Stine found 4 out of 16 subjects were classified as class III and IV lupus nephritis by renal biopsy, but these subjects had normal creatinine and slightly increase urine protein. Other possibility of false positive result is increased disease activity in other organs. Katsumata et al. ${ }^{9}$ stated that anti-C1q serum was correlated with global lupus activity and not specifically correlated with active lupus nephritis.

The result of this study is different from other studies that produce a good validity of anti-C1q serum. The limitation of this study is using SLE patients that have been receiving therapy.

\section{CONCLUSION}

Based on this study, anti-C1q assay has a low sensitivity and moderate specificity to detect lupus nephritis, therefore anti-C1q serum cannot be used solely to detect lupus nephritis. The actual validity of anti-C1q serum to detect lupus nephritis is still to be proven in further studies.

\section{REFERENCES}

1. Kasjmir $\mathrm{Yl}$, Handono K, Wijaya LK, Hamijoyo L, Albar Z, Kalim H. Rekomendasi Perhimpunan Reumatologi Indonesia Untuk Diagnosis dan Pengelolaan Lupus Eritematosus Sistemik. Jakarta: Perhimpunan Ahli Penyakit Dalam Indonesia; 2011.

2. Hahn BH, McMahon MA, Wilkinsil A, Wallace WD, Daikh DI, Fitzgerald JD, et al. American College of Rheumatology Guidelines for Screening, Treatment, and Management of Lupus Nephritis. Arthritis Care $\&$ Research 2012;64(6):797-808.

3. Salgado AdZ, Herrera-Diaz C. Lupus Nephritis: An overview of recent findings. Autoimmune Diseases 2012;2012:1-21.

4. Yazdany J, Dall'Era M. Definition and Classification of Lupus and LupusRelated Disorders. In: Wallace DJ, Hahn BH, editors. Dubois' Systemic Lupus Erythematosus and Related Syndrome. 8th ed. Philadelphia: Elsevier Saunders; 2013. p. 1-3.

5. Mahler M, Schaarenburg RAV, A. Trouw L. Anti-C1q autoantibodies, novel tests, and clinical consequences. Front Immunol 2013:4:117.

6. Pickering MC, Botto M. Are anti-C1q antibodies different from other SLE autoantibodies?. Nat Rev Rheumatol 2010;6:490-3.

7. Moura CGG, Mangueira CLP, Cruz LAS, Cruz CMS. Negative anti-C1q Antibody Titers May Influence Therapeutic Decisions and Reduces Renal Biopsies in Systemic Lupus Erythematosus. Nephron Clin Pract. 2011;18:355-60.
8. Meyer OC, Roland PN, Cadoudal N, Mignot SG, Palazzo E, Hayem G, et al. Anti-C1q antibodies antedate patent active glomerulonephritis in patients with systemic lupus erythematosus. Arthritis Research \& Therapy 2009 (11):1-8.

9. Katsumata $Y$, Miyake K, Kawaguchi $Y$, Okamoto $Y$, Kawamoto M, Gono $T$, et al. Anti-C1q antibodies are associated with systemic lupus erythematosus global activity but not specifically with nephritis. Arthritis Rheum 2011;63(8):2436-44.

10. Heidenreich U, Mayer G, Herold M, Klotz W, Stempfl K, Al-Jazrawi, et al. Sensitivity and specificity of autoantibody tests in the differential diagnosis of lupus nephritis. Lupus. 2009;18:1276-80.

11. Lehman TJA. SLE in Childhood and Adolescence. In: Wallace DJ, Hahn BH, editors. Dubois' Systemic Lupus Erythematosus and Related Syndrome. 8th ed. Philadelphia: Elsevier Saunders; 2013. p. 495-7.

12. Dooley MA. Clinical and epidemiologic features of lupus nephritis. In: Wallace DJ, Hahn BH, editors. Dubois' Lupus Erythematosus and Related Syndrome. 8th ed. Philadelphia: Elsevier Saunders; 2013. p. 438-52.

13. Chong BF, Werth VP. Skin Disease in Cutaneous Lupus Erythematosus. In: Wallace DJ, Hahn BH, editors. Dubois' Systemic Lupus Erythematosus and Related Syndrome. 8th ed. Philadelphia: Elsevier Saunders; 2013. p. 319-30.

14. Navarra SV, Torralba TP. The Musculoskeletal System and Bone Metabolism. In: Wallace DJ, Hahn BH, editors. Dubois' Systemic Lupus Erythematosus and Related Syndrome 8th ed. Philadelphia: Elsevier Saunders; 2013. p. 333-8.

15. Ishimori M, Weisman MH, Katy Setoodeh, Wallace DJ. Principles of Therapy, Local Measures, and Nonsteroidal Medications. In: Wallace DJ, Hahn BH, editors. Dubois' Lupus Erythematosus and Related Syndrome. 8th ed. Philadelphia: Elsevier Saunders; 2013. p. 583.

16. Hegazy A, Barakat AF, Gayyar MAE, Arafa LF. Prevalence and clinical significance of anti-C1q antibodies in cutaneous and systemic lupus erythematosus. The Egyptian Journal of Medical Human Genetics 2012;13:167-71.

17. Cai $X$, Yang $X$, Lian F, Lin $X$, Liang $M$, Li J, et al. Correlation between serum anti-C1q antibody levels and renal pathological characteristics and prognostic significance of anti-C1q antibody in lupus nephritis. J Rheumatol. 2010;37:759-65.

18. Mannik M, Wener M. Deposition of antibodies to the collagen-like region of $\mathrm{C} 1 \mathrm{q}$ in renal glomeruli of patients with proliferative lupus glomerulonephritis. Arthritis Rheum. 1997;40:1504-11.

19. Christopher-Stine L, Siedner M, Lin J, Haas M, Parekh H, Petri M. Renal Biopsy in Lupus Patients with Low Levels of Proteinuria. J Rheumatol 2007:34:332-5.

20. Vargas-Arenas RE, Tápanes F, Daboin I, Pinto JA, Bianco NE, ZabaletaLanz M. Silent Lupus Nephritis. Inmunología. 2004;23(3):278-83. 